\title{
Study and Design of Subsea Foundation; Design of RCC Subsea Laboratory (Special Composite Structure) to be Built at MIT, Pune Campus
}

\author{
Ameer Talib $^{1}$, Dr. Mrudula S Kulkarni \\ ${ }^{1,2}$ Department of Structural Engineering Maharashtra Institute of Technology (MIT), Pune, India
}

\begin{abstract}
Now Days Subsea engineering is perhaps one in every of the foremost necessary, Yet the most difficult aspects of offshore fossil fuel business. Wherever temperature, pressure and corrosion testing instrumentation and submerged underwater production environment the strength of equipment subsea engineers, specifically deepwater operation presents specific challenges. Most subsea engineering operations automation and remote processes and water on the surface of the parts to repair is up less space. Subsea production system installation and operation of the availability of some unique aspects linked to and who is sexual intercourse sex. Special trains professionals, tools and fossil fuels used in offshore production infrastructure for a subsea offshore engineering equipment were built. Subsea flow assurance solid (for example, -hydrates, paraffin, asphaltenes, scale and sand) can be given as, and integrated fluid management properties, corrosion is a dynamic, production needs to maintain processes in multiphase subsea environment. Flow assurance design and low temperature, high internal hydrostatic pressure and offset and high availability due to a mixture of economic drivers for action on deep water difficult. Subsea subsea young dynamic engineers completely different topics to explore various aspects of engineering for engineering provides a unique opportunity. Aker solutions and Maharashtra Institute of technology, Pune initiated awareness and subsea engineering students engineering related education among different subjects to promote him.
\end{abstract}

Keywords: analysis and design of subsea lab, Subsea engineering lab, Maharashtra institute of technology, Pune campus

\section{Introduction}

The project is essentially the complete planning, analysis and design of a Subsea laboratory to be erected in the college campus, in collaboration with Aker Solutions, the leading Subsea system company. The project is challenging due to the unconventional layout of the building, and the different needs of the structure as it's a public building with a live water tank, and huge girder cranes moving around in the open space of the building. The laboratory in question is a smaller scale simulation of the actual drilling and processing of oil from the deeper ocean beds, with various machinery that are built in the factories, and then are later assembled underwater. All the components of the system are intact, and are miniaturized version of the actual system. The laboratory consists of a water tank that has the capacity to hold 4 lakh liters of water, a reservoir to hold the oil that will be used to simulate the working of the system, open space for the working of the girder cranes, control rooms situated on the mezzanine floor and some classrooms for the students to study in. The structure is 4 stories tall, with a substructure height of $8.53 \mathrm{~m}$ and an underground height of 6.64 meters. The tank is 3.2 meters deep and has dimensions of $11 \mathrm{~m} \mathrm{x}$ $10 \mathrm{~m}$.

\subsection{The definition of the foundation and its types}

The substructure or foundation is the part of a structure that is usually placed below the surface of the ground. Footings and foundations for the structure of soil or rock texture to transfer load to support other units. Generally supported soil must quite weak soils walls concrete column interaction between areas because a \& members backed by vast levels between $\& \&$. Footings (1.1) are illustrated in the figure of the more common types. Strip footings or wall footings essentially one-dimensional action, cantilevering out on each side of the wall display. The column was spread over an area of soil around the column Footings are loads delivered to pad.

Distribute the load in two directions. Sometimes to save the step level content spread equal pedestals. To load a pile Cap column piles, which in turn, in some depth below the surface level of a strong layer and transmits a series of difficult to transmit. Soils in the United post footings to load two or more columns. Often used when a property row is a column level. A mat or raft Foundation soil transfer all columns in a building designed to load in. Mat Foundation is very weak soils, are experiencing. Geo-technical engineers as well as Foundation type option is selected. Factors to be considered are:

- The soil strength,

- The soil type,

- The variability of the soil type over the area and with increasing depth, and

- The susceptibility of the soil and the building to deflections.

The most basic and most common types are strip, spread, combined footings. 


\section{International Journal of Science and Research (IJSR)}

ISSN (Online): 2319-7064

Index Copernicus Value (2013): 6.14 | Impact Factor (2015): 6.391

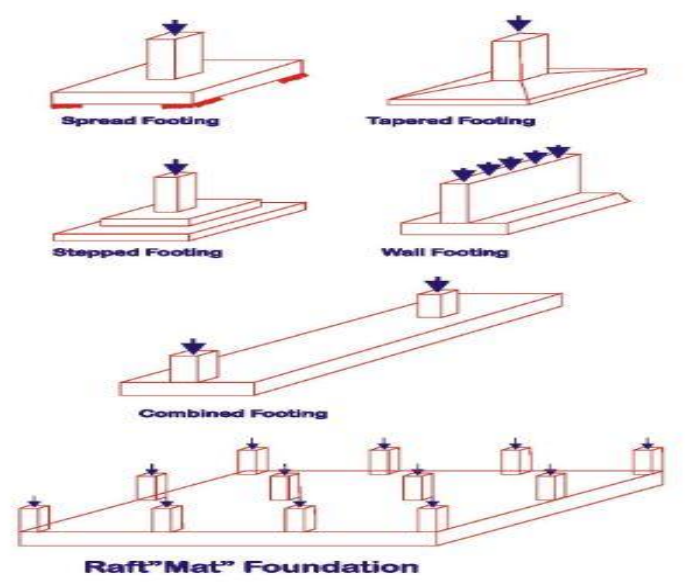

Figure 1.1: Footing Types

\subsection{Rigid Method}

The simplest approach to structural design of mats is the rigid method (also known as the conventional method or the conventional method of static equilibrium). Meaning no distortion inherent soil bearing distribution, more rigorous mat and pressure mat only apply the weight of the load and the mat (kendrick (geometric) and a second general works, current through the load) mat effect on either uniform across the bottom of the method assumes linear transformation or shown depends too small to (a cross-like or moment load eccentric mat if present In figure (1.2) is) this same assumption used in the analysis of simple spread footings.

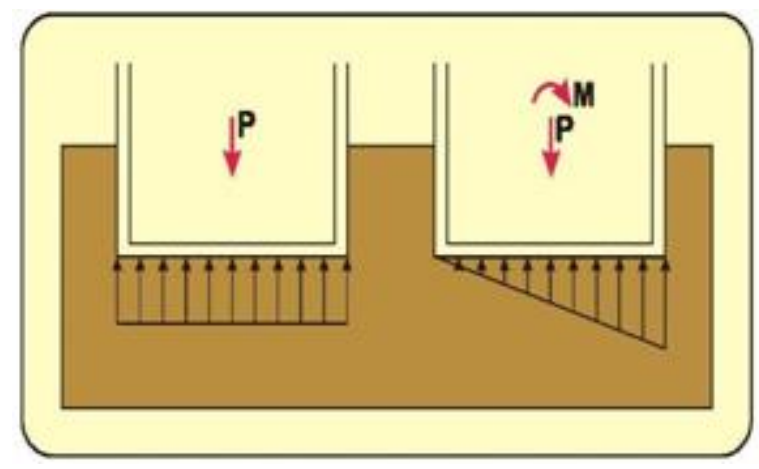

Figure 1.2: Analysis of spread footings

This simple distribution makes it easy to compute the flexural stresses and deflections (differential settlements) in the mat. Analysis an inverted mat and just loaded twoway slab, meaning the principles of structural mechanics, moments and scissors easily by using the deflection will be calculated for the purposes of can. Engineers can choose the appropriate \& reinforcement mat thickness. It gets to the right, although this type of analysis is appropriate to spread footings, width-thickness ratio is very high, and mats of perception no longer valid mat Foundation model.

\subsection{Types of foundation}

Marine foundations are being executes to transmit structural design loadings to the subsoil. The types depend on

- The nature of loading
- The stiffness and strength of the surface sediments,

- The desires of the builder.

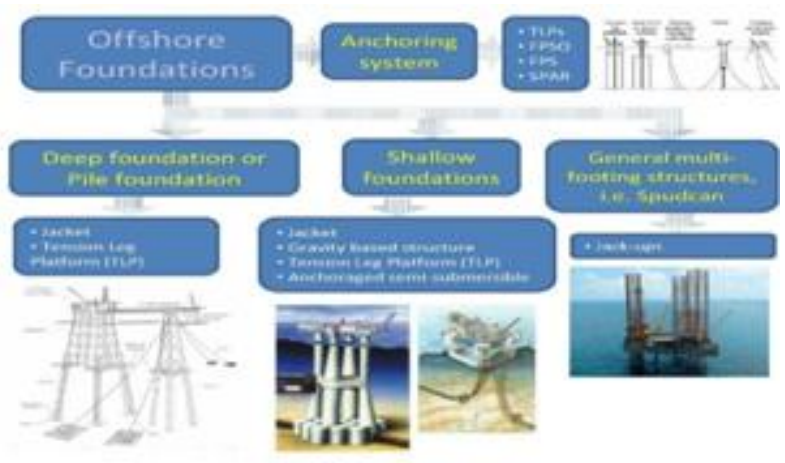

Figure 1.3: Types of foundation
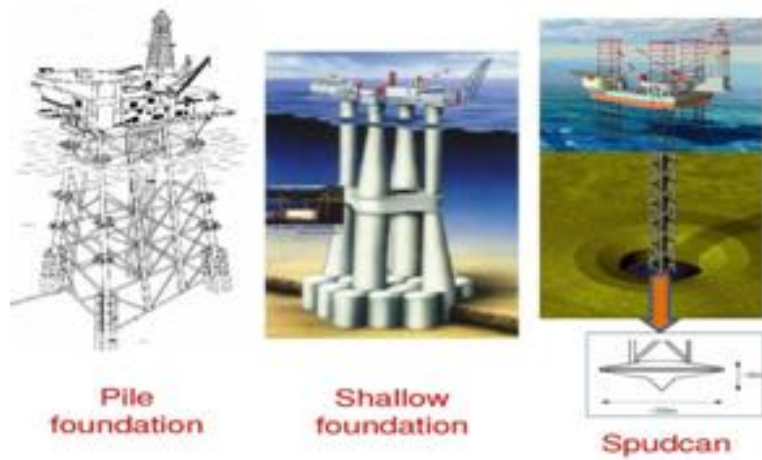

Figure 1.4: Types of foundation

\section{Objective, Scope and Limitations}

\section{Objectives}

The objective of our project is to plan, analyses and design the lab structurally and foundation, considering all the various components and the requirements of the structure. The project is especially challenging due to the presence of an irregular plan, a huge water tank and immense loads on the girder crane, moving and stationary. The onsite undulations make it even more challenging.

\section{Limitations}

There are no limitations to this study, as this is a real world project and the results of this project shall be applied to the real structure.

\section{Scope}

The scope of this project is restricted to the overall planning, analysis the structure. and design of foundation and column

\section{Review of Literature}

X. FENG, M. F. RANDOLPH, S. GOURVENEC and R. WALLERAND presented an alternative design method, based on failure envelopes derived from an extensive Programme of three-dimensional finite-element analyses, focusing on the sliding and rotational capacity of the foundation. Starting from expressions that quantify the uniaxial capacity under each of the six degrees of freedom, failure envelope shapes for different biaxial combinations are developed. Ultimately, the allowable capacity under the six-degree-of-freedom loading is expressed in terms of a two-dimensional failure envelope for the resultant horizontal 


\section{International Journal of Science and Research (IJSR) \\ ISSN (Online): 2319-7064 \\ Index Copernicus Value (2013): 6.14 | Impact Factor (2015): 6.391}

and moment loading, after due allowance for the vertical and torsional components of load.

Robert B. Gordon, Guttorm Grytøyr and Mayuresh DhaigudeSuction pile splash area to reduce process modeling through a direct time domain is described. Its long axis with a relatively small installation especially oriented on surface of the water with almost parallel paper pile stack detects. Time domain simulation model of the crane Sling wire or mail/ Pile system consists of. This system Crane-Tip, on loading, and is subject to hydrodynamic flooding the vessel motions.

Harry G. Poulos and Grahame Bunce (2008), The author's describes the foundation design process adopted for the Burj Dubai, The world's tallest building. Pile raft Foundation system, deep mud and rocks carbonate deposits is established. Newspapers began, geotechnical investigations and design processes, and program framework region test lab and discusses how various design issues, wind loading, including skin friction will cause a cyclical decline were addressed. Numerical computer analysis check/ Calibration analysis underscored the original design, and alternative analysis of the peer-review process will be described planned was adopted.

Suman M. Sharma, Mayur G. Vanza, and Dhumketu D. Mehta (2014) In this Paper, study is carried out for comparison of "Raft foundation" and "Beam and Slab Raft foundation". Excel spread sheet (manual) analysis and design raft Foundation is ready. Beam and slab raft Foundation analysis and Excel spread sheet (manual) and is built using STAAD Pro. Software. In this paper, analysis and design of tall building to consider the Foundation for cost-effective geotechnical and structural design aspects. Quantitative study of soil bearing capacity has been different values.

M.J. Pender, T. B. Algie, L. B. Storie and R. Salimath, Both rocking designs that are shallow foundations, forcing paper-based and displacement-based structure-Foundation systems can include in design presents a vision. Law Foundation and the moment a certain rigidity on vertical load rocking small strain elastic estimates. These two soilFoundation parameters Foundation a moment-rotation nonlinear curve limit; Hyperbolic curve provides a smooth transition between the border.

\section{Subsea Foundation}

A foundation is a structure that transfers loads to the earth. Foundations generally are divided into two categories: shallow foundations deep foundations. A subsea production structure with piles, nudmats or seabed may be supported by straight skirt. Also these three formations can be supported by combining.

\subsection{Pileor Skirt-Supported Structures}

A pile-supported structure of foundation piles for compression, tension, lateral loads, and even shear stress should be designed as applicable. Stack to structure/ Skirt is connected properly (see Figure 4.1.). It's a mechanical device or grouting pile and can be accomplished by the annulus between the sleeves.

\section{Seabed-Supported Structures}

Seabed-supported structure in question to the Foundation of vertically and horizontally the load bearing capacity is designed to be sufficient. Based on Seabed conditions, high contact stress can develop. This should be considered in the design. Base grouting and distribution to achieve required stability under load on the seabed may have to be used.

\subsection{Pile and Plate Anchor Design and Installation}

\section{Basic Considerations}

The technology for the evaluation of the geotechnical capacity of a suction pile and plate anchor is still under development; therefore, Specific and detailed recommendations can be given at this point. Instead, General statements indicate that consideration should be given to a few points and are used for reference. Designer available to them all the research advances are encouraged to use. It is hoped that more specific recommendations may be issued after completion of the research in this area.

\begin{tabular}{llll} 
& \multicolumn{2}{c}{ Type of Installation Vessel for Different Foundations } \\
\cline { 3 - 4 } GeographylVessel & Drilling Rig & Pipe Lay Barge/Construction Vessel \\
\hline Soil & Hard & - & Mudmat \\
Conditions & Medium & Suction pile & Mudmat or suction pile \\
& Soft & Suction pile & Suction pile \\
\hline
\end{tabular}
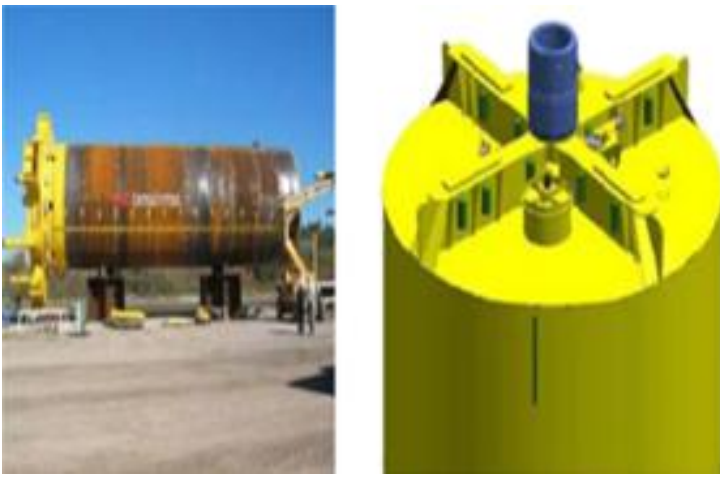

Figure 4.1: Suction pile

\subsection{Load Combinations}

Maximum power and maximum stress and distortion effect for purposes of combining design load and consequently will be produced. A partial safety factor dead load weight may be considered with the following combination is appropriate

+ Imposed Load

- $\mathrm{DL}+\mathrm{IL}+$ wind or earthquake load

- $\mathrm{DL}+\mathrm{Wind} /$ Earthquake

- DL + Erection Load

Wind load and earthquake loads shall not be assumed to act simultaneously. The effect of each shall be considered separately.

Vertical loads, vertical, lateral loads, influence factors (growth) and longitudinal (horizontal) challenges, as well, 


\section{International Journal of Science and Research (IJSR) \\ ISSN (Online): 2319-7064}

Index Copernicus Value (2013): 6.14 | Impact Factor (2015): 6.391

And crane rail eccentricity effects to be considered under the influence of weighting imposed respectively inspired by crane will be included with no acting. Crane loads and their combination to be used by the client to be treated as indicated. In the absence of any specific indication 875 will load combinations or as being in accordance with the provisions below:

- Vertical impact as many cranes, two cranes with load operation without full effects are loaded with a loaded crane or Crane loads only in case of vertical coupled with maximum horizontal force or two operations can be located for maximum effectiveness;

- multi-bay multi crane gantries loads for building maximum cross section in any two of the section Cranes under, will be treated as specified in.

- longitudinal thrust on a crane track cranes loaded on rail track a maximum of two will be considered;

Thrust (growth) and lateral and longitudinal thrust acting crane rail with respectively, will be considered not work simultaneously. Though the effects of each force individually examined.

\section{Research Analysis}

This section shows the different analysis of the work which is done practically as follow

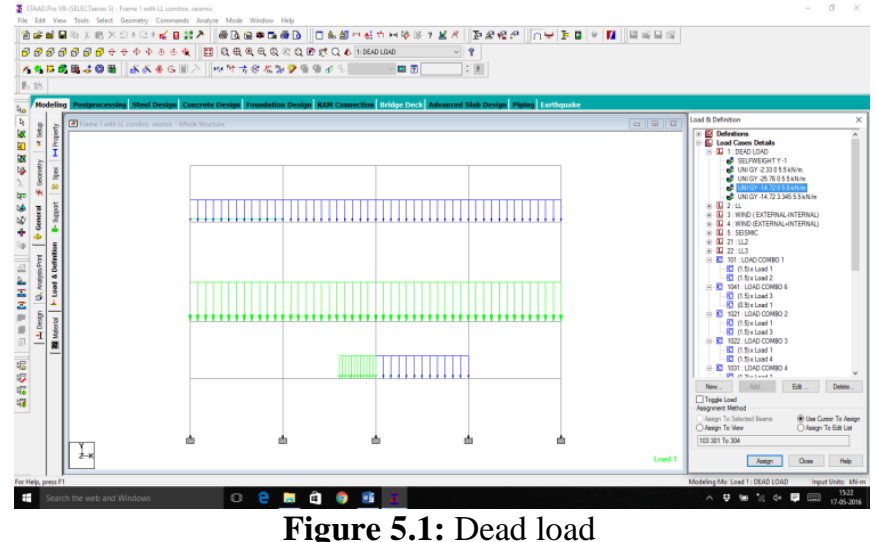

Figure 5.1: Dead load

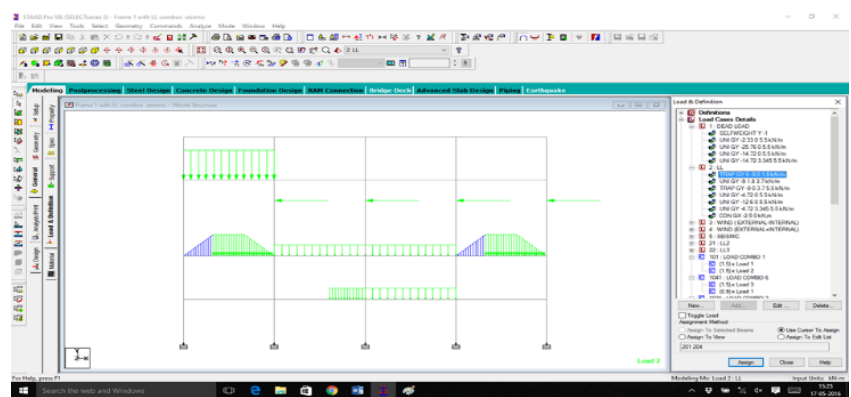

Figure 5.2: Live load

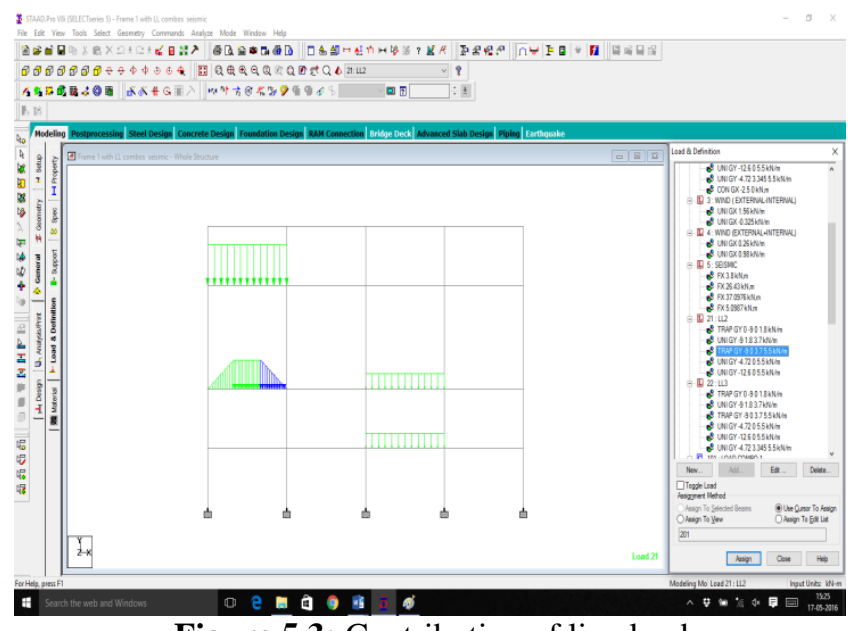

Figure 5.3: Contribution of live load

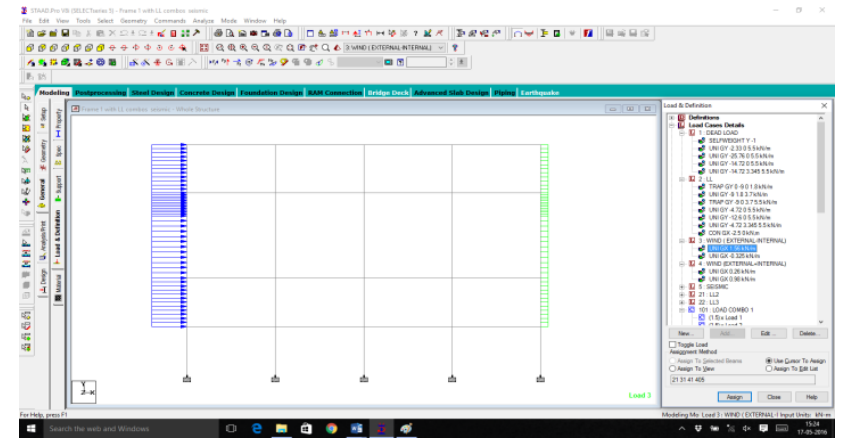

Figure 5.4: Wind load

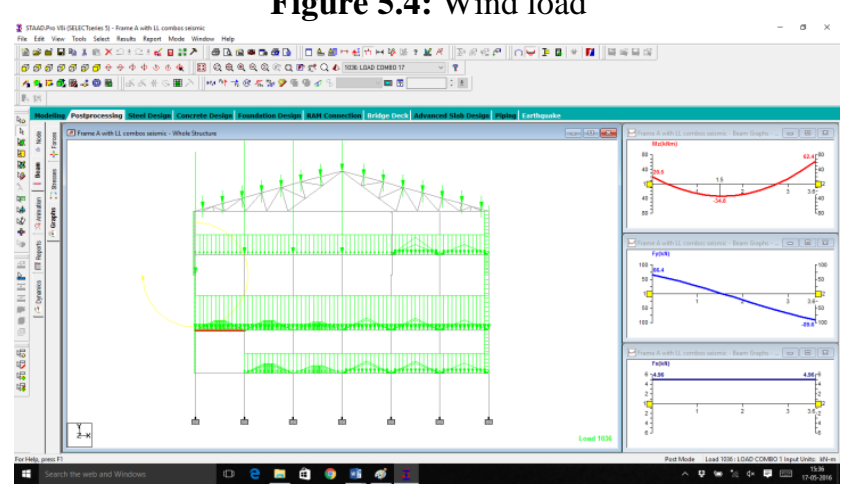

Figure 5.5: Fully loaded load combination

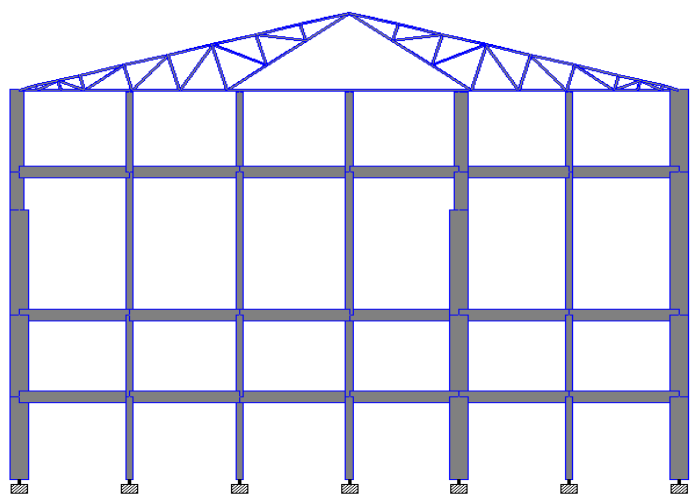

Volume 5 Issue 6, June 2016 www.ijsr.net 


\section{International Journal of Science and Research (IJSR) \\ ISSN (Online): 2319-7064}

Index Copernicus Value (2013): 6.14 | Impact Factor (2015): 6.391

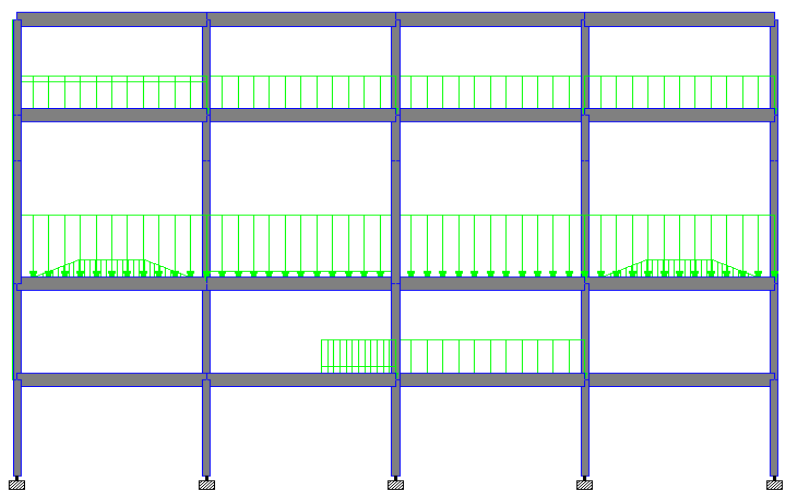

Figure 5.6: FRAME A Full Section; FRAME 1 Full Section

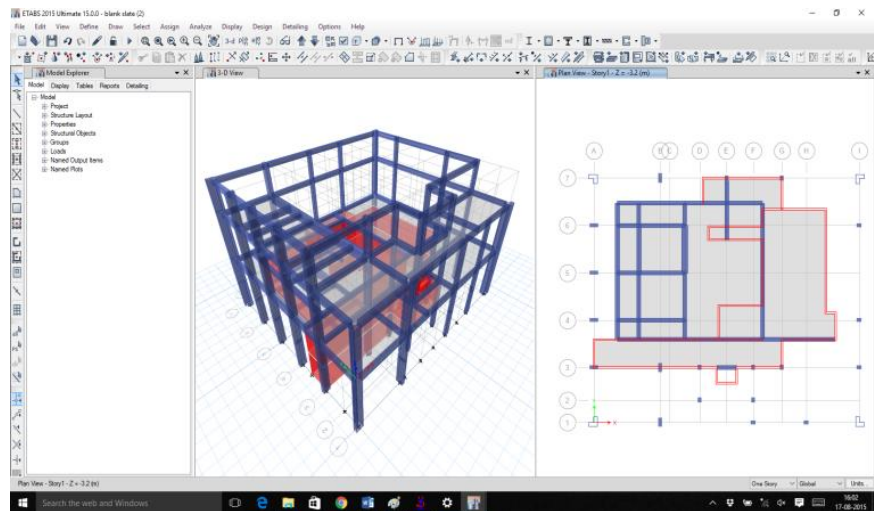

Figure 5.7: With the actual sections of the frames extruded

\section{Results Design}

\section{Design Column}

Column is an important element of every reinforced concrete structure these are used to transfer the load to the foundation safely. Mainly columns strut and pedestals are used as compression members in buildings, bridges, supporting of tanks, factories .and many more such structures. A column is defined as a vertical compression member which is mainly subjected to axial load \& the effective size of which increased three time its least lateral dimension.

in this chapter chosen rectangular,eccentrically, short and R.C.C column calculate the load used of software STAAD Pro V8i and design the column use Microsoft Excel 2010. SP 16: Design Aids for Concrete Design by IS 456:2000

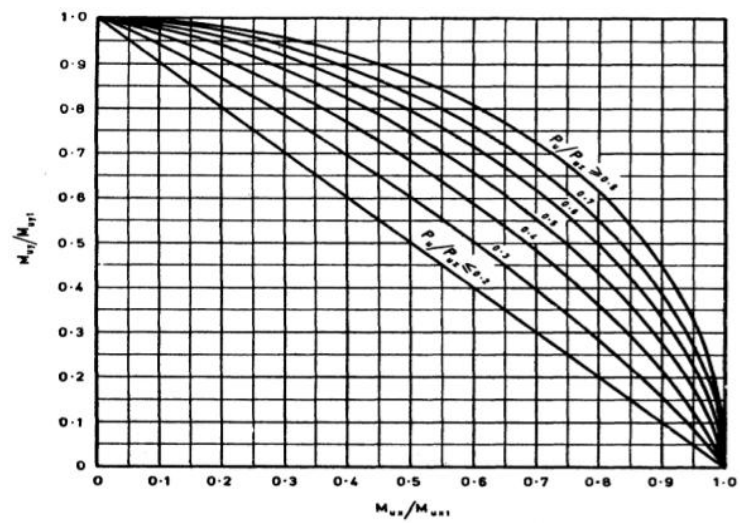

Figure 6.1: Compression with bending rectangular sectionreinforcement distributed equally of four sider

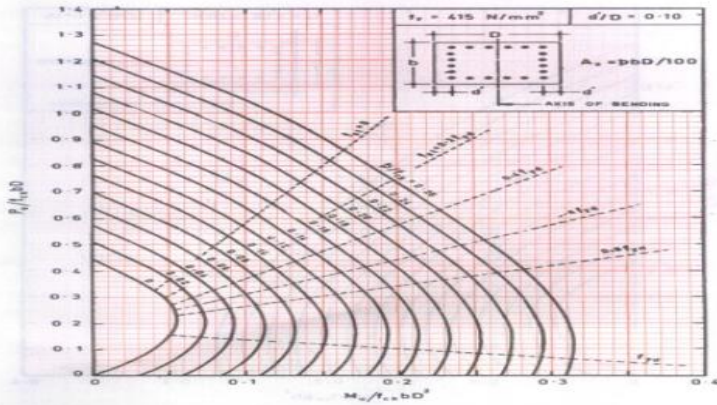

Figure 6.2: Compression with bending rectangular sectionreinforcement distributed equally of four sider

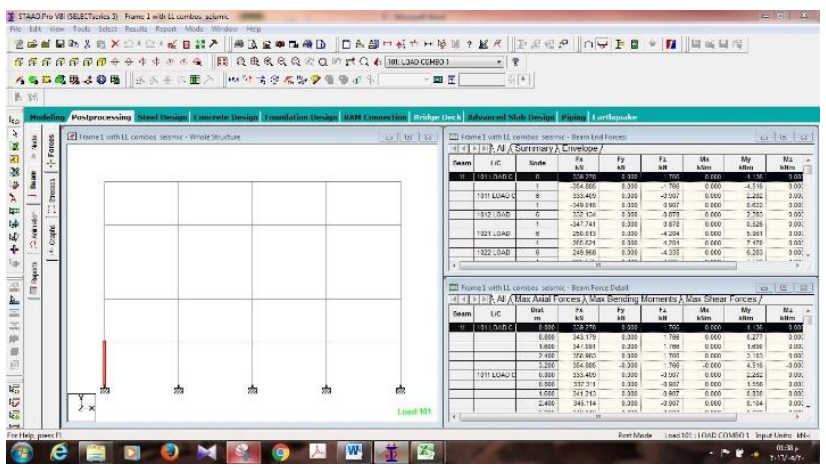

Figure 6.3: Frame $1 \mathrm{Fx}-\mathrm{Fz}-\mathrm{My}$

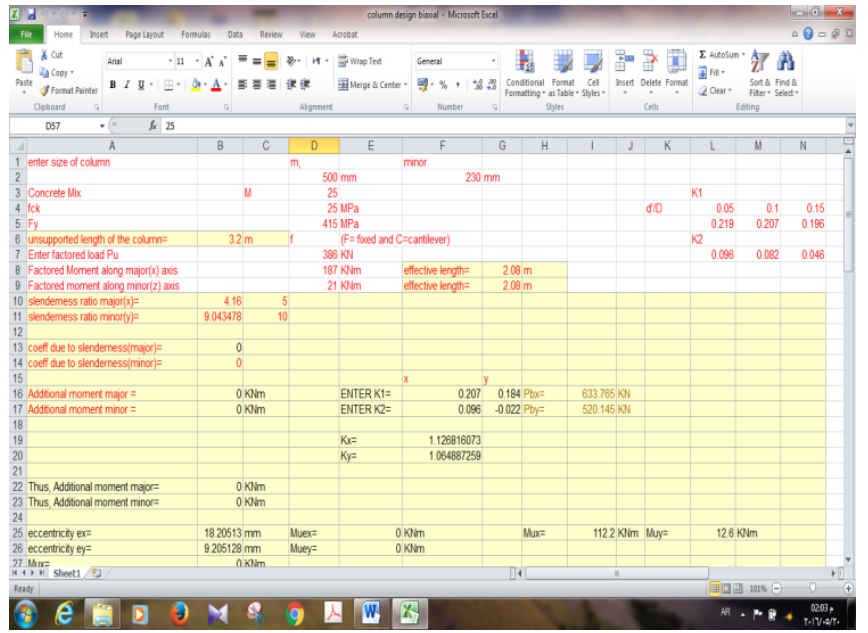

Figure 6.4: The calculate of the designer use excel sheet

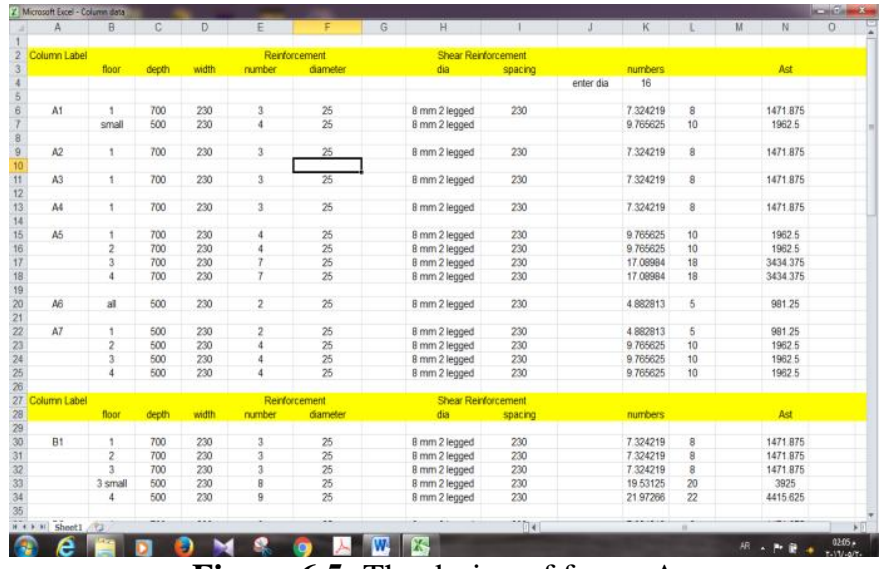

Figure 6.5: The design of frame A

\section{Volume 5 Issue 6, June 2016 www.ijsr.net}




\section{International Journal of Science and Research (IJSR) \\ ISSN (Online): 2319-7064}

Index Copernicus Value (2013): 6.14 | Impact Factor (2015): 6.391

\section{Design footing}

Usually part of a side or Foundation structure that is placed below the surface of the ground.

Footings and foundations for the structure of soil or rock texture to transfer load to support other units.

Soil generally supported walls concrete columns should be quite weak because soil $\&$ interaction between regions is a member supported by huge levels amongst.

Strip footings or wall footings essentially onedimensional action, cantilevering out on each side of the wall display.

Spread over an area of soil around the column Footings to pad the column are distributed load

The design of footing use

- Size of column $500 * 230,700 * 230$

- Bearing capacity of the soil $400 \mathrm{KN} / \mathrm{m}^{\wedge} 2$

- Loads on columns (Reaction)

- Use M 25 concrete and Fe 415 steel

- Code IS: 456:2000

- Excel sheet

STAAD Pro V8i

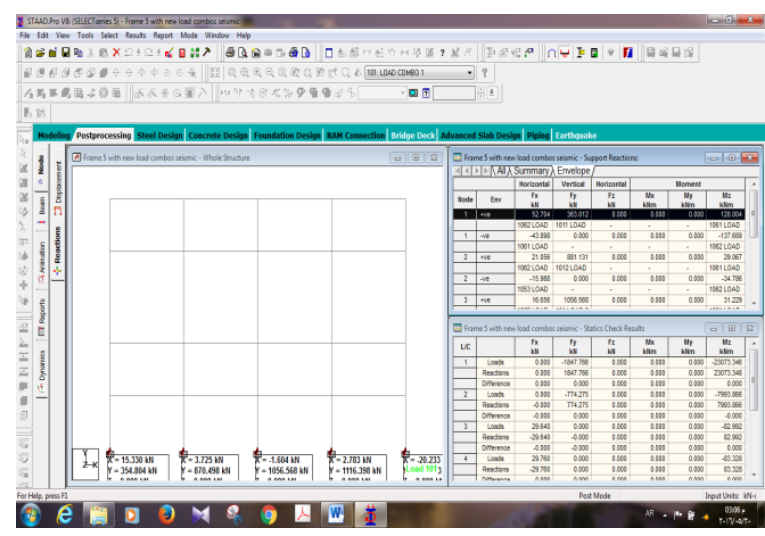

Figure 6.6: Reaction of column

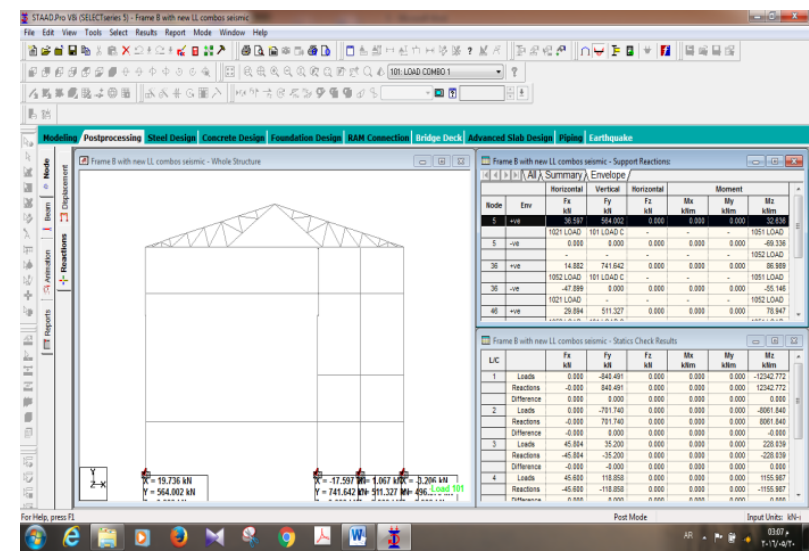

Figure 6.7: (reaction)

\section{Conclusion}

This research has looked, therefore, at the analysis and design of subsea engineering lab, focusing on the how built the structure of subsea labs in Maharashtra institute of technology. It has been seen that this study has been done in pune campus with the great focus on the problems and observation of the labs. According to a survey conducted with the practical analysis and design working whole thesis designed according to research goal The project is challenging due to the unconventional layout of the building, and the different needs of the structure as it's a public building with a live water tank, and huge girder cranes moving around in the open space of the building.

\section{References}

[1] IS 456: 2000: Design of Plain and Reinforced Concrete.

[2] SP 16: DESIGN AIDS FOR IS 456: 2000 FOR REINFORCED CONCRETE DESIGN

[3] IS 875: 1987 (Part 1): PART 1 DEAD LOADS UNIT WEIGHTS OF BUILDING MATERIALS AND STORED MATERIALS

[4] IS 875: 1987 (Part 2): CODE OF PRACTICE FOR LIVE DESIGN LOADS

[5] IS 875: 1987 (Part 3): CODE OF PRACTICE FOR WIND DESIGN LOADS

[6] IS 875: 1987 (Part 5): CODE OF PRACTICE FOR SPECIAL DESIGN LOADS

[7] IS 807: 2006: DESIGN, ERECTION AND TESTING ( STRUCTURAL PORTION ) OF CRANES AND HOISTS - CODE OF PRACTICE

[8] IS 1893: 2002: CRITERIA FOR EARTHQUAKE RESISTANT DESIGN OF STRUCTURES

[9] IS 800: 2007: GENERAL CONSTRUCTION IN STEEL: CODE OF PRACTICE

[10] X. FENG, M. F. RANDOLPH, S. GOURVENEC and R. WALLERAND " Design approach for rectangular nudmats under fully three-dimensional loading "Volume 64 Issue 1, January 2014, pp. 51-63

[11] Robert B. Gordon, Guttorm Grytøyr and Mayuresh Dhaigude " Modeling Suction Pile Lowering Through the Splash Zone" ASME 2013 32nd International Conference on Ocean, Offshore and Arctic Engineering, OMAE2013-10136, pp. V001T01A010; 9 pages, doi:10.1115/OMAE2013-10136

[12] Harry G. Poulos and Grahame Bunce "foundation design for the burj dubai-final3 - Geomarc Ltd" case histories in geotechnical engineering, Arlington, VA, August 11-16-2008

[13] Suman M. Sharma, Mayur G. Vanza, and Dhumketu D. Mehta, "Comparison of Raft Foundation and Beam \& Slab Raft Foundation for High Rise Building", (IJEDR), ISSN:2321-9939, Vol.2, Issue 1, pp.571-575, March 2014,

\section{Volume 5 Issue 6, June 2016 www.ijsr.net}

